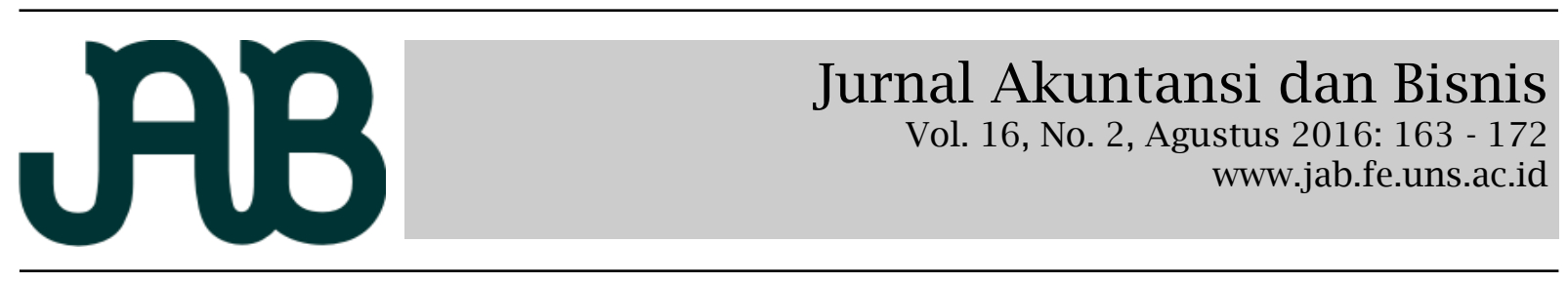

\title{
AMBIGUITAS INFORMASI PADA PENGAMBILAN KEPUTUSAN AUDIT
}

\author{
SITI RAHAYU PUJI LESTARI \\ INTIYAS UTAMI (intiyas@staff.uksw.edu)
}

Program Studi Akuntansi FEB UKSW

\begin{abstract}
A B S T R A C T
The aim of this research is to examine the impact of ambiguity information in the decision making audit. This study used factorial experiment method $1 \times 2$ between subjets with 72 participants of the undergraduate Accounting students. The data was analyzed by using independent t-test and analysis of variance (ANOVA). In this study, information ambiguity were manipulated into three levels: insufficient/ complex; sufficient/complex; sufficient/not complex. The result shows that ambiguity level had a negative effect on the accuracy of audit decision. The empirical evidence provided that insufficient/complex data cause infomation ambiguity and impact to the auditor's inaccurate in decision-making.

Keywords: information ambiguity, audit judgement, complexity, sufficiency

Tujuan penelitian ini adalah untuk mengetahui dampak ambiguitas informasi dalam pengambilan keputusan audit. Penelitian ini menggunakan metoda eksperimen faktorial $1 \times 2$ antarsubjek dengan 72 partisipan mahasiswa S1 Akuntansi. Data dianalisis menggunakan independent t-test dan analysis of variance (ANOVA). Dalam penelitian ini ambiguitas informasi dimanipulasi dalam tiga level: tidak cukup/ komplek; cukup/komplek; dan cukup/tidak komplek. Hasil penelitian menunjukkan bahwa ambiguitas informasi mempunyai efek negatif terhadap keakuratan pengambilan keputusan. Bukti empiris membuktikan bahwa data tidak cukup/komplek dapat menyebabkan ambiguitas informasi dan dampaknya adalah ketidakuratan keputusan audit.

Kata kunci: ambiguitas informasi, keputusan audit, kompleksitas, kecukupan
\end{abstract}

\section{PENDAHULUAN}

Isu penelitian ini tentang ambiguitas informasi yang berdampak pada pengambilan keputusan dalam konteks audit. Idealnya, informasi yang digunakan dalam pengambilan keputusan audit harus didasarkan pada bukti yang tepat yaitu relevan dan realibel. Terpaparnya ambiguitas informasi dalam proses pengumpulan bukti berdampak negatif terhadap pengambilan keputusan audit. Koonce (1993) telah meneliti tentang ambiguitas informasi dalam bidang audit; medis, dan psikologi yang menunjukkan bahwa, hipotesis dihasilkan pada proses awal pengambilan keputusan yang kemudian digunakan untuk memandu pengumpulan data lebih lanjut. Ketidakakuratan penilaian akhir sering disebabkan karena kegagalan auditor dalam membuat hipotesis awal yang tidak akurat (Bedard dan Biggs 1991).

Penelitian Luippold dan Kida (2012) serta Utami dan Nahartyo (2016) memberikan bukti empiris bahwa penyebab utama hipotesis yang tidak akurat adalah ambiguitas informasi. Luippold dan Kida (2012) berpendapat bahwa ambiguitas informasi merupakan sekumpulan informasi yang dapat menyebabkan berbagai interpretasi. Utami dan Nahartyo (2016) dalam penelitiannya menyatakan bahwa ambiguitas informasi dalam konteks audit adalah bias informasi. Auditor bisa terpapar bias informasi pada saat melakukan prosedur analitis, misalnya memahami sifat dan jenis industri klien.

Standar audit yang berlaku secara umum salah satunya adalah standar pekerjaan lapangan. Dalam standar lapangan ketiga auditor harus memperoleh cukup 
bukti untuk mendukung kualitas pendapat auditor. Kecukupan merupakan salah satu persuasif bukti. Informasi yang cukup menambah keyakinan auditor untuk membuat keputusan yang tepat. Kompleksitas informasi berkaitan dengan kuantitas informasi. Banyaknya informasi bisa menguntungkan dan memberikan keyakinan bagi para auditor untuk membuat keputusan yang tepat, namun informasi yang komplek perlu ditimbang lagi kesusiannya dengan tugas pengauditan. Terdapat dua variabel utama penyebab ambiguitas informasi menurut Luippold dan Kida (2012) yaitu kecukupan data dan kompleksitas data. Kecukupan mengacu pada bukti yang komprehensif (Luippold dan Kida 2012), menurut Utami dan Nahartyo (2016) kecukupan informasi adalah informasi yang disajikan relevan. Kompleksitas informasi adalah banyaknya informasi yang terkandung dalam data (Hogarth dan Einhorn 1992). Utami dan Nahartyo (2016) pada penelitiannya telah memberi temuan empiris bahwa ambiguitas berdampak ketidakakuratan pengambilan keputusan audit dan group support system (GSS) dapat mengurangi ambiguitas informasi.

Akuntabilitas seorang akuntan publik (auditor) ditentukan dari kualitas laporan audit yang dibuat. Laporan audit dapat dipertangggungjawabkan apabila didasarkan pada bukti yang tepat dalam setiap keputusan audit. Liburd et al. (2015) berpendapat bahwa informasi yang tidak relevan dapat menyebabkan hambatan dalam menganalisis dan dapat mempengaruhi kualitas audit. Pengambilan keputusan audit dapat dipengaruhi oleh banyak hal, seperti suasana hati yang dapat mempengaruhi penilaian auditor (Cianci dan Bierstaker 2009), terbebani tugas yang banyak karena memiliki banyak klien juga dapat mempengaruhi penilaian audit (Bhattacharjee et al. 2013). Prasita dan Adi (2007) serta Cahyaningrum dan Utami (2015) memberikan bukti empiris bahwa kompleksitas dapat menyebabkan ketidakakuratan dalam pengambilan keputusan audit sehingga kualitas audit yang dihasilkan buruk. Penelitian Luippold dan Kida (2012) juga sependapat bahwa kompleksitas informasi dapat menyebabkan ketidakakuratan dalam pengambilan keputusan sehingga kualitas yang dihasilkan rendah.

Ambiguitas informasi menjadi tantangan bagi auditor untuk mengumpulkan, menganalisis dan mempersatukan informasi yang beragam dari sumber yang berbeda saat penugasan audit. Einhorn dan Hogarth (1986) menyatakan bahwa ambiguitas informasi timbul dari jumlah dan jenis informasi yang tersedia; perbedaan keandalan sumber dan kurangnya pengetahuan atas peristiwa yang diamati. Liburd et al. (2015) dalam penelitiannya menjelaskan bahwa keterbatasan dan pengolahan informasi yang lemah dapat menghambat keefektifan big data dalam konteks audit. Temuan Liburd et al. (2015) menyimpulkan bahwa informasi yang overload, informasi yang tidak relevan dan ambiguitas informasi menjadikan keterbatasan utama dalam analisis big data yang harus dihadapi auditor. Ketika auditor terpapar ambiguitas maka akan menghasilkan kualitas audit yang buruk. Situasi problematika seperti ini menjadi tantangan dan hambatan bagi auditor, terlebih lagi auditor dituntut untuk menciptakan good govermence.

Penelitian ini merupakan pengembangan dari penelitian Luippold dan Kida (2012) serta Utami dan Nahartyo (2016). Ambiguitas informasi menjadi tiga tingkatan yaitu: cukup dan tidak komplek; cukup dan komplek; dan tidak cukup dan komplek. Desain penelitian laboratorium eksperimental pada riset terdahulu dan memberikan bukti secara empiris bahwa ambiguitas informasi mempunyai pengaruh negatif terhadap keakuratan pengambilan keputusan audit. Penelitian ini menguji ambiguitas informasi dengan menggunakan tatanan eksperimen yang berbeda dari penelitian sebelumnya. Kecukupan informasi difokuskan pada relevansi bukti audit. Kompleksitas informasi disajikan dalam bentuk kuantitas informasi. Hal ini selaras dengan standar audit bahwa bukti audit yang cukup dan kompeten harus diperoleh oleh auditor. Tujuan penelitian ini untuk menguji dampak ambiguitas informasi pada pengambilan keputusan audit. Hasil penelitian ini diharapkan dapat memberikan kontribusi menambah 
riset empiris tentang ambiguitas informasi dalam penugasan audit. Secara praktis penelitian ini diharapkan mampu memberikan kontribusi bagi para auditor dalam memilih informasi yang relevan untuk pengambilan keputusan audit.

\section{KAJIAN PUSTAKA DAN RUMUSAN HIPOTESIS \\ Ambiguitas Informasi}

Utami dan Nahartyo (2016) dalam penelitiannya berpendapat bahwa ambiguitas informasi dalam konteks audit adalah bias informasi. Auditor bisa terkena bias informasi pada saat melakukan prosedur analitis, misalnya memahami sifat dan jenis industri klien. Auditor harus memperoleh cukup bukti dengan melakukan prosedur audit agar memiliki dasar yang layak untuk memberikan pendapat audit. Bukti audit tidak akan menjadi cukup dan tepat untuk dijadikan penilaian jika datanya ambigu. Ambiguitas informasi timbul dari jumlah dan jenis informasi yang tersedia, keandalan sumber informasi dan kurangnya pengetahuan atas peristiwa yang diamati (Einhorn dan Hogarth 1986). Data yang tidak terstruktur akan menjadi data yang ambigu dan ambiguitas informasi menghasilkan kesalahan penilaian auditor misalnya ketidakakuratan mengidentifikasi kasus error dan kurang konservatif dalam penilaian going concern (Luippold dan Kida 2012). Liburd et al. (2015) dalam penelitianya yang membahas kelemahan dalam pengolahan informasi analisa big data menyatakan bahwa ambiguitas merupakan salah satu potensi keterbatasan big data. Informasi yang disajikan secara ambigu dalam big data apabila informasinya tidak jelas, tidak lengkap dan tidak terstruktur.

Penentu ambiguitas informasi ada dua variabel yaitu kecukupan data dan kompleksitas data. Kecukupan data mengacu pada informasi yang diperlukan untuk dijadikan bukti sampai pada penilaian akhir. Utami dan Nahartyo (2016) berpendapat bahwa kecukupan informasi mengacu pada informasi yang relevan. Menurut Luippold dan Kida (2012) kecukupan dan kelengkapan data merupakan variabel yang berbeda namun saling berhubungan, variabel kecukupan data merupakan variabel yang lebih penting dalam menentukan keakuratan penilaian. Ada dua point yang mendasari perbedaan tersebut menurut Luippold dan Kida (2012), pertama data yang tidak lengkap tidak berarti tidak cukup, misalnya seorang dokter dapat mendiagnosa penyakit tertentu tanpa harus melakukan tes kesehatan secara menyeluruh pada tubuh pasien. Perbedaan yang kedua adalah data yang lengkap tidak selalu cukup untuk membuat keputusan, meskipun mempunyai informasi yang lengkap namun belum cukup untuk membuat keputusan yang akurat. Kompleksitas data merupakan variabel kedua yang menentukan ambiguitas informasi. Hogarth dan Einhorn (1992) berargumen bahwa kompleksitas data merujuk pada jumlah informasi yang terkandung dalam setiap bukti atau panjangnya bukti yang disajikan. Sependapat dengan Chung dan Monroe (2001) kompleksitas juga dipengaruhi oleh banyaknya informasi yang tidak relevan dengan kejadian yang diaudit. Luippold dan Kida (2012) dalam penelitian nya berargumen jika dalam sebuah kasus terdapat cukup data untuk membuat keputusan yang akurat, namun datanya sangat komplek sehingga perlu dieliminasi informasi yang berpotensi menimbulkan ketidakakuratan.

\section{Keputusan Audit}

Dalam penelitian Liburd et al. (2015) menyatakan bahwa seseorang yang mempunyai kemampuan untuk mengumpulkan, mengelola, dan menganalisis data dengan efektif memiliki potensi penilaian yang lebih baik untuk pengambilan keputusan. Auditor dalam melakukan audit memiliki tugas menilai resiko dan materialitas, mengumpulkan bukti, dan memutuskan apakah buktinya sudah cukup untuk mendukung laporan audit. Keputusan audit menentukan kualitas audit dan kualitas laporan keuangan terkait. Auditor menilai estimasi akuntansi yang wajar, metode akuntansi yang tepat dan menilai pengendalian internal atas laporan keuangan apakah berfungsi secara memadai (Griffith et al. 2016). Keakuratan hipotesis awal merupakan faktor penting dalam pembuatan keputusan akhir selama prosedur ana- 
litis (Luippold dan Kida 2012)

\section{Perumusan Hipotesis}

Ambiguitas informasi dalam konteks audit timbul dari kegagalan auditor dalam memahami sifat bisnis atau industri klien dan tidak mampu memproses informasi dengan baik sehingga dapat berpotensi mengakibatkan pengambilan keputusan yang tidak akurat. Luippold dan Kida (2012) dalam hasil penelitiannya memberikan bukti bahwa data yang tidak cukup dan komplek merupakan penyebab ambiguitas informasi yang dapat menghasilkan keputusan yang tidak akurat. Utami dan Nahartyo (2016) juga berpendapat sama bahwa ambiguitas informasi dapat menimbulkan dampak negatif pada pengambilan keputusan. Penelitian ini mengadopsi tiga tingkatan ambiguitas informasi yang didasarkan pada penelitian terdahulu yaitu Luippold dan Kida (2012) serta Utami dan Nahartyo (2016): (1) data yang cukup dan komplek; (2) data yang tidak cukup dan komplek; (3) data yang cukup dan tidak komplek. Peneliti berarugumen bahwa informasi yang disajikan secara komplek dan idak cukup adalah informasi yang berpotensi menyebabkan ambiguitas informasi. Informasi yang komplek adalah informasi yang banyak, panjang dan rumit, sedangkan informasi yang tidak cukup adalah informasi yang disajikan secara tidak relevan dengan tugas yang dilaksanakan.

Berdasarkan argumentasi yang dikemukakan dan hasil penelitian terdahulu, maka hipotesis yang diajukan adalah:

H1a: Subjek yang menerima informasi cukup dan komplek akan lebih akurat pengambilan keputusannya dibandingkan subjek yang menerima informasi tidak cukup komplek.

H1b: Subjek yang menerima informasi cukup dan tidak komplek akan lebih akurat pengambilan keputusannya dibandingkan subjek yang menerima informasi cukup dan komplek.

H1c: Subjek yang menerima informasi cukup dan tidak komplek akan lebih akurat pengambilan keputusannya dibandingkan subjek yang menerima informasi tidak cukup dan komplek.

\section{METODA PENELITIAN \\ Desain Penelitian}

Desain penelitian ini adalah eksperimen laboratorium antarsubjek (between subject). Variabel independen atau variabel yang dimanipulasi adalah ambiguitas informasi. Tingkatan ambiguitas terdiri dari tiga tingkatan yaitu cukup dan komplek; tidak cukup dan komplek; cukup dan tidak komplek. Variabel ambiguitas diadopsi dari penelitian terdahulu yaitu Luippold dan Kida (2012) serta Utami dan Nahartyo (2016). Variabel dependennya yaitu keputusan audit atas penilaian dari sistem pengandalian internal dengan nilai antara 10-100. Semakin mendekati nilai 100 dianggap mempunyai sistem pengendalian internal yang handal.

Partisipan diberi tugas untuk menilai sistem pengendalian internal dari siklus penjualan perusahaan. Informasi yang diberikan kepada partisipan berupa modul, terdapat tiga modul yang masing-masing merefleksikan tiga tingkatan ambiguitas yang terdiri dari uji pemahaman dan manipulasi informasi. Partisipan diminta untuk berkelompok sesuai dengan jenis modul yang diperoleh dan diberikan jarak antar partisipan supaya tidak ada diskusi. Dalam pengerjaannya dipandu eksperimenter oleh karena itu tidak ada pertanyaan yang terlewatkan dan tidak ada partisipan yang dapat membuka halaman sebelumnya atau halaman berikutnya tanpa perintah.

\section{Subjek penelitian}

Penelitian ini melibatkan mahasiswa sebagai subjek penelitian. Subjek diminta untuk berperan sebagai auditor yunior dalam tatanan simulasi audit. Mahasiswa sebagai penyulih dari auditor yunior. Alasan mahasiswa sebagai penyulih auditor yunior berdasarkan asumsi bahwa mahasiswa sudah lulus mata kuliah pengauditan dan dapat bekerja sebagai auditor yunior. Tugas prosedur analitis tidak perlu dikerjakan oleh auditor senior atau kepala audit, karena dalam penugasan tersebut tidak memerlukan pengalaman yang banyak. Dalam penelitian ini, partisipan dipilih secara acak tanpa membeda-bedakan tingkat kemampuan atau kepandaian, jenis kelamin dan usia, sebagai bentuk randomisasi. 
Tatanan Eksperimen

Eksperimen dilakukan dalam tiga tahap. Setiap tindakan (manipulasi) dilanjutkan dengan pertanyaan pengecekan manipulasi. Apabila peserta dapat menjawab dengan benar $50 \%$ dari pertanyaan yang diberikan, maka lolos pengecekan manipulasi. Berikut adalah tahapan eksperimen:

\section{Tahap 1}

Dalam eksperimen tahap 1, partisipan diberikan informasi bahwa dirinya adalah seorang auditor yunior yang bekerja disebuah Kantor Akuntan Publik dan mendapat tugas untuk menilai sistem pengendalian internal siklus penjualan pada sebuah perusahaan nasional. Partisipan diberikan tiga pertanyaan yang menguji seberapa paham partisipan tentang perannya sebagai auditor eksternal yang berkerja untuk mengaudit sistem pengendalian internal siklus penjualan. Pertanyaan tersebut terlampir pada uji prestasi 1.

Uji selanjutnya adalah pastisipan diuji tentang teori yang menunjukkan tingkat pengetahuan partisipan mengenai teori yang mereka dapatkan saat perkuliahan. Uji pengetahuan yang ditanyakan adalah mencari ratio keuangan, prosedur analitis, dokumen-dokumen audit dan pengendalian internal.

Partisipan juga diberikan informasi tentang aktivitas perusahaan dan profil perusahaan yang didiskripsikan secara visual melalui gambar dan narasi tentang sistem pengendalian internal dari siklus penjualan yang dilakukan oleh klien. Selanjutnya partisipan diuji tentang seberapa paham mengenai profil perusahaan klien dengan 3 pertanyaan.

Dalam uji prestasi 1 dan 3 terdapat masing-masing 3 pertanyaan, jika partisiapan dapat menjawab minimal 2 pertanyaan (50\%) dengan benar maka dianggap paham dengan perannya sebagai auditor yunior dan paham mengenai profil perusahaan klien. Dalam uji prestasi 2 semakin banyak pertanyaan yang dijawab dengan benar menunjukkan partisipan sangat menguasai materi pengauditan. Partisipan melanjutkan ketahap 2.

Tahap 2
Standar audit yang berlaku umum menetapkan bahwa proses audit harus didasarkan pada bukti yang cukup dan tepat. Menurut Luippold dan Kida (2012) dan Utami dan Nahartyo (2016) kecukupan berkenaan dengan jumlah bukti dan kelengkapan informasi yang dibutuhkan untuk pengambilan keputusan yang tepat dan relevan. Faktor ambiguitas yang kedua adalah kompleksitas data, data dikatakan komplek jika data tersebut panjang dan rumit (Hogarth dan Einhorn 1992).

Dalam tahap 2 partisipan diberikan manipulasi berupa informasi yang sesuai dengan tingkatan ambiguitas untuk masing -masing modul. Informasi yang diberikan kepada partisipan dalam modul 1 adalah data yang dimanipulasi dengan tingkatan ambiguitas (tidak cukup dan komplek) yaitu data yang disajikan banyak tetapi tidak relevan untuk sistem pengendalian internal siklus penjualan.

Data yang diberikan sebagai berikut: (1) PT HGI berdiri sejak tahun 1990; (2) Perusahaan membeli bahan baku berdasarkan pesanan. (3) Perusahaan memilih karyawan yang berkompeten untuk menangani investasi dan surat berharga; (4) Perusahaan memiliki staf administrasi kantor sekaligus administrasi keuangan; (5) Perusahaan melakukan penghematan listrik untuk bagian kantor; (6) Otorisasi penjualan dilakukan oleh petugas yang berwenang; (7) Mempunyai petugas keamanan yang handal untuk menjaga keamanan; (8) Perusahaan melakukan corporate and social responsibility (CSR) untuk lingkungan disekitar pabrik; (9) Untuk meningkatkan kemampuan karyawan baru dilakukan pelatihan karyawan; (10) Setiap tahun ada kenaikan gaji untuk karyawan; (11) Setiap karyawan diberikan tunjangan kesehatan. Dari 11 informasi yang disediakan hanya informasi nomer 6 saja yang relevan dengan sistem pengendalian internal siklus penjualan yaitu otorisasi penjualan dilakukan oleh petugas yang berwenang.

Dalam modul 2 informasi yang diberikan kepada partisipan adalah data yang diberi tingkatan ambiguitas (cukup dan komplek) informasi yang tersedia banyak namun sudah cukup relevan untuk sistem pengendalian internal siklus 
penjualan. Datanya sebagai berikut: (1) PT HGI berdiri sejak tahun 1990; (2) Perusahaan membeli bahan baku berdasarkan pesanan, (3) Perusahaan memilih karyawan yang berkompeten untuk menangani investasi dan surat berharga; (4) Perusahaan memiliki staf administrasi kantor sekaligus administrasi keuangan; (5) Perusahaan melakukan penghematan listrik untuk bagian kantor; (6) Penjualan dilakukan oleh staf yang berpengalaman; (7) Penjualan dilakukan terkomputerisasi; (8) Otorisasi penjualan dilakukan oleh manager penjualan; (9) Faktur penjualan terkomputerisasi yang tercetak urut nomer dan dicetak rangkap tiga sebagai dokumen; (10) Mempunyai petugas keamanan yang handal untuk menjaga keamanan; (11) Perusahaan melakukan corporate and social responsibility (CSR) untuk lingkungan disekitar pabrik. Informasi yang disediakan ada 11 informasi, tetapi hanya 4 informasi saja yang relevan dengan sistem pengendalian internal siklus penjualan yaitu informasi nomer 6, 7, 8 dan 9 .

Dalam modul 3 berisikan informasi dengan tingkatan ambiguitas (tidak komplek dan cukup), semua informasi yang disediakan relevan dengan sistem pengendalian internal siklus penjualan. Informasinya seperti berikut: Penjualan dilakukan oleh staff yang berpengalaman; (2) Penjualan dilakukan terkomputerisasi; (3) Otorisasi penjualan dilakukan manager penjualan; (4) Faktur penjualan terkomputerisasi yang tercetak urut nomer dan dicetak rangkap tiga sebagai dokumen; (5) Adanya pemisahan fungsi antara karyawan yang bertugas menerima pesanan dan menerima pelunasan; (6) Setiap karyawan bagian penjualan yang melakukan kecurangan akan ditindak secara hukum; (7) Setiap karyawan baru khususnya bagian penjualan diseleksi secara selektif untuk mendukung sistem penjualan yang baik; (8) Penjualan bisa dilakukan secara tunai maupun kredit; (9) Selektif dalam memilih pelanggan dalam melakukan penjualan barang secara kredit; (10) Mempunyai dokumen pelanggan yang memiliki track record baik dalam melakukan pelunasan; (11) Rajin mengikuti pameran dan bazar untuk menarik pelanggan. Semua informasi yang disediakan relevan dengan sistem pengendalian internal siklus penjualan.

Tahap 3

Dalam tahap 3 partisipan diminta untuk memberikan nilai atas sistem pengendalian internal perusahaan klien. Nilai yang diberikan antara 10-100. Partisipan memberikan nilai 50-100 jika menilai sistem pengendalian internal siklus penjulan klien memadai dan handal, sebaliknya partisipan memberikan nilai diantara 10-49 jika menganggap SPI siklus penjulan klien tidak memadai.

\section{Teknis Analisis}

Pengujian pertama yaitu menguji keefektifan randomisasi dengan uji One Way Analysis of Varian (ANOVA). Pengujian randomisasi dimaksudkan untuk memberi kepastian bahwa penelitian ini tidak dikacaukan oleh perbedaan karakteristik demografi. Dalam penelitian ini hanya manipulasi yang dapat mempengaruhi variabel dependen (keputusan audit) bukan karena perbedaan karakteristik demografi. Pengujian berikutnya adalah pengujian hipotesis yang menggunakan uji independent t-test. Hipotesis terdukung apabila menghasilkan signifikansi probabilistik 2 tailed dibawah 0,05 yang artinya terdapat perbedaan yang signifikan antara grup eksperimen dan grup kontrol.

\section{ANALISIS DAN PEMBAHASAN \\ Gambaran Umum Partisipan}

Subjek dalam penelitian ini adalah 76 mahasiswa S1 dari Sekolah Tinggi Ilmu Ekonomi Perbanas Surabaya (STIE Perbanas). Tahap pertama dilakukan pengecekan manipulasi atas peran dan tugas sebelum pengujian yang lebih lanjut. Pengecekan manipulasi dilakukan untuk mengetahui apakah partisipan paham dengan peran dan tugasnya sebagai auditor yunior dalam simulasi audit. Subjek dikatakan lolos pengecekan manipulasi, apabila subjek dapat menjawab minimal dua pertanyaan (50\%) dengan benar, dari tiga pertanyaan yang disajikan. Adapun karakteristik demografi partisipan masing - masing meliputi 4 kategori yaitu jenis kelamin, usia, Indek Prestasi Kumulatif dan 
semester. Berikut ini subjek yang lolos pengecekan manipulasi.

Tabel 1.

Pengecekan Manipulasi

\begin{tabular}{|c|c|c|c|}
\hline No & $\begin{array}{l}\text { Manipulasi } \\
\text { Informasi }\end{array}$ & $\mathbf{N}$ & $\begin{array}{c}\text { Hasil Pen- } \\
\text { gecekan Ma- } \\
\text { nipulasi }\end{array}$ \\
\hline 1 & $\begin{array}{l}\text { Tidak cukup dan } \\
\text { komplek }\end{array}$ & 25 & 23 \\
\hline 2 & $\begin{array}{l}\text { Cukup dan kom- } \\
\text { plek }\end{array}$ & 25 & 23 \\
\hline 3 & $\begin{array}{l}\text { Cukup dan tidak } \\
\text { komplek }\end{array}$ & 26 & 26 \\
\hline & Jumlah peserta & 76 & 72 \\
\hline
\end{tabular}

Subjek yang lolos pengecekan manipulasi sebanyak tujuh puluh dua (72) peserta dari tujuh puluh enam (76) peserta. Terdapat enam puluh empat (64) peserta berjenis kelamin wanita dan delapan (8) peserta berjenis kelamin laki - laki. Paling banyak berusia dua puluh (20) tahun yaitu empat puluh tujuh (47) peserta. Jumlah partisipan rata - rata mempunyai IPK 3,00 - 3,49 dan sedang mengambil semester 5 .

\section{Uji Randomisasi}

Sebelum melakukan pengujian hipotesis dilakukan terlebih dahulu uji randomisasi. Pengujian ini dilakukan untuk memastikan bahwa perbedaan karakteristik demografi tidak berpengaruh terhadap pengambilan keputusan. Berdasarkan uji one way anova menunjukkan bahwa karakteristik demografi jenis kelamin, usia, IPK dan semester tidak mempunyai pengaruh yang signifikan terhadap pengambilan keputusan audit. Pengaruh karakteristik jenis kelamin terhadap pengambilan keputusan audit menunjukkan signifikansi sebesar $(p=$ 0,886 ), usia tingkat signifikansinya sebesar $(p=0,181)$, IPK tingkat signifikansi sebesar $(p=0,438)$, dan semester tingkat signifikansinya sebesar $(p=0,145)$. Hasil pengujian statistik tersebut lebih besar daripada tingkat signifikansi yang digunakan yaitu 0,05. Hasil tersebut memberikan kesimpulan bahwa perbedaan karakteristik demografi partisipan tidak mempunyai pengaruh yang signifikan terhadap pengambilan keputusan audit. Hasil uji randomisasi dapat dilihat di dalam tabel 2.

Tabel 2.

Pengujian Randomisasi

\begin{tabular}{lccc}
\hline & $\begin{array}{c}\text { Mean } \\
\text { Squares }\end{array}$ & F & Sig \\
\hline Jenis kelamin & 6,250 & 0,021 & 0,886 \\
Usia & 512,848 & 1,755 & 0,181 \\
IPK & 250,150 & 0,834 & 0,438 \\
Semester & 575,858 & 1,983 & 0,145 \\
\hline
\end{tabular}

\section{Uji Hipotesis}

Tabel 3 menunjukkan hasil pengujian hipotesis dengan menggunakan uji independent t-test. Dari pengujian hipotesis dapat dilihat bahwa penelitian ini mendukung penelitian terdahulu yaitu Luippold dan Kida (2012) serta Utami dan Nahartyo (2016) yang memberikan bukti empiris bahwa ambiguitas informasi berdampak negatif terhadap pengambilan keputusan audit.

Hipotesis pertama menguji individu yang menerima informasi cukup dan komplek dibandingkan dengan yang menerima informasi tidak cukup dan komplek. Hasil pengujian menunjukkan kelompok partisipan yang memperoleh informasi cukup dan komplek memiliki nilai rata-rata 75,65 sedangkan nilai rata-rata kelompok partisipan yang memperoleh data tidak cukup dan komplek sebesar 58,69. Nilai probabilitas signifikan sebesar 0,001 ( $p<$ $0,05)$. Hasil tersebut menunjukkan bahwa ada perbedaan signifikan antara kedua kelompok. Dalam pengujian ini terbukti bahwa kelompok yang menerima informasi cukup dan komplek lebih akurat untuk membuat keputusan dibandingkan dengan kelompok yang membuat keputusan dari informasi tidak cukup dan komplek. Temuan ini sejalan dengan temuan Utami dan Nahartyo (2016) bahwa ketika individu diberikan informasi yang cukup meskipun komplek akan membuat keputusan yang lebih baik. Informasi yang cukup adalah informasi yang relevan dengan bukti yang 
dicari dalam penugasan audit.

Liburd et al. (2015) berpendapat bahwa informasi yang tidak relevan dapat menyebabkan hambatan dalam menganalisis. Kompleksitas informasi akan menambah beban tugas auditor dan akan berdampak negatif dengan hasil audit. Temuan ini mendukung penelitian Chung dan Monroe (2001), Prasita dan Adi (2007) dan Cahyaningrum dan Utami (2015) bahwa kompleksitas audit berdampak negatif terhadapat kualitas audit. Informasi yang komplek berhubungan dengan banyaknya informasi (Hogarth dan Einhorn 1992). Banyaknya informasi yang disajikan belum pasti semua informasi tersebut sesuai dengan bukti yang dibutuhkan untuk pengambilan keputusan audit. Hasil penelitian ini juga memberikan kebenaran atas pendapat Luippold dan Kida (2012) bahwa informasi yang komplek bukan berarti informasi tersebut cukup untuk membuat keputusan.

Pengujian hipotesis yang kedua yaitu menunjukkan bahwa hipotesis H1b tidak terdukung oleh hasil pengujian. Nilai rata rata kelompok partisipan yang memperoleh informasi cukup dan tidak komplek sebesar 80,76 dan nilai rata - rata kelompok partisipan yang menerima informasi cukup dan komplek memperoleh 75,65 . Hasil uji statistik menunjukkan tidak ada perbedaan yang signifikan antara kedua kelompok. Terbukti dari hasil pengujian menunjukkan hasil signifikansi probabilistik sebesar 0,094 ( $p>0,05)$. Hal tersebut menunjukkan bahwa subjek tidak terpengaruh oleh informasi yang disajikan. Hasil ini sependapat dengan temuan Utami dan Nahartyo (2016) bahwa diantara informasi cukup dan tidak komplek dan informasi cukup dan komplek menghasilkan perbedaan yang tidak signifikan. Temuan ini juga mendukung penelitian Prasita dan Adi (2007) bahwa kompleksitas dalam tugas pengauditan menyebabkan kualitas audit yang buruk, baik karena variabilitas, peran dan tugas yang komplek. Cahyaningrum dan Utami (2015) mengemukakan argumen yang sama bahwa kompleksitas audit dapat berpengaruh negatif terhadap keputusan audit. Semakin rumit tugas yang diberikan kepada auditor maka auditor akan semakin ragu dalam menentukan potensi salah saji klien.

Tabel 3.

Pengujian Hipotesis

\begin{tabular}{|c|c|c|c|c|c|c|}
\hline $\begin{array}{l}\text { Level } \\
\text { ambigui- } \\
\text { tas }\end{array}$ & $\begin{array}{c}\text { Nilai } \\
\text { rata- } \\
\text { rata }\end{array}$ & $\begin{array}{c}\text { Standa } \\
\text { r de-- } \\
\text { viasi }\end{array}$ & Min & Max & $\mathbf{F}$ & Sig \\
\hline \multicolumn{7}{|c|}{ Hipotesis 1a } \\
\hline $\begin{array}{l}\text { Cukup } \\
\text { komplek } \\
(\mathrm{N}=23)\end{array}$ & 75,65 & 10,79 & 40 & 90 & \multirow{2}{*}{9,381} & \multirow{2}{*}{$\begin{array}{c}0,00 \\
1\end{array}$} \\
\hline $\begin{array}{l}\text { Tidak } \\
\text { cukup } \\
\text { komplek } \\
(\mathrm{N}=23)\end{array}$ & 58,69 & 20,95 & 10 & 80 & & \\
\hline \multicolumn{7}{|c|}{ Hipotesis 1b } \\
\hline $\begin{array}{l}\text { Cukup } \\
\text { tidak } \\
\text { komplek } \\
(\mathrm{N}=26)\end{array}$ & 80,76 & 10,16 & 60 & 100 & \multirow[t]{2}{*}{0,100} & \multirow{2}{*}{$\begin{array}{c}0,09 \\
4\end{array}$} \\
\hline $\begin{array}{l}\text { Cukup } \\
\text { komplek } \\
(\mathrm{N}=23)\end{array}$ & 75,65 & 10,79 & 40 & 80 & & \\
\hline \multicolumn{7}{|c|}{ Hipotesis 1c } \\
\hline $\begin{array}{l}\text { Cukup } \\
\text { tidak } \\
\text { komplek } \\
(\mathrm{N}=26)\end{array}$ & 80,76 & 10,16 & 60 & 100 & \multirow{2}{*}{$\begin{array}{c}10,08 \\
2\end{array}$} & \multirow{2}{*}{$\begin{array}{c}0,00 \\
0\end{array}$} \\
\hline $\begin{array}{l}\text { Tidak } \\
\text { cukup } \\
\text { komplek } \\
(\mathrm{N}=23)\end{array}$ & 58,69 & 20,95 & 10 & 80 & & \\
\hline
\end{tabular}

Hasil pengujian hipotesis terakhir menunjukkan bahwa subjek yang menerima informasi cukup dan tidak komplek lebih akurat dalam membuat keputusan dibandingkan dengan subjek yang menerima informasi tidak cukup dan komplek. Nilai rata - rata individu yang menerima informasi cukup tidak komplek $(80,76)$ dan individu yang menerima informasi tidak cukup dan komplek $(58,69)$. Hasil uji statistik menunjukkan signifikansi sebesar $(p=0,000)$ lebih kecil dari pada 0,05. Artinya menunjukkan perbedaan yang sangat signifikan diantara kedua kelompok tersebut. Informasi yang disajikan secara cukup dan tidak komplek memberikan keyakinan bagi auditor karena informasi yang disajikan relevan dengan SPI klien, sedangkan informasi yang tidak cukup dan komplek menunjukkan bahwa SPI klien lemah dan tidak dapat meyakinkan auditor. Kompleksitas informasi menunjukkan bahwa informasi tersebut terlalu banyak dan dapat mempengaruhi auditor, sehingga 
perlu dieliminasi informasi yang dapat mempengaruhi penilaian auditor. Temuan itu sependapat dengan pendapat Luippold dan Kida (2012) informasi yang komplek bukan berarti sudah cukup untuk membuat keputusan, dan sebaliknya informasi yang tidak komplek bukan berarti tidak cukup membuat keputusan. Hasil pengujian hipotesis ketiga mendukung hipotesis H1c, bahwa keputusan yang didasarkan oleh informasi cukup dan tidak komplek lebih akurat dibandingkan dengan yang memperoleh informasi tidak cukup dan komplek. Hasil penelitian ini meyakinkan kembali tentang temuan Luippold dan Kida (2012) serta Utami dan Nahartyo (2016) bahwa informasi tidak cukup dan komplek paling beresiko menyebabkan ketidakakuratan jika dibandingkan dengan informasi cukup tetapi komplek dan cukup tidak komplek. Informasi yang cukup menambah keyakinan auditor untuk membuat keputusan yang tepat.

\section{SIMPULAN DAN IMPLIKASI Simpulan}

Tujuan penelitian ini untuk menguji dampak ambiguitas informasi pada pengambilan keputusan audit. Penelitian ini berhasil memberikan bukti empiris bahwa ambiguitas informasi menyebabkan ketidakakuratan dalam pengambilan keputusan audit. Temuan ini mendukung penelitian terdahulu Luippold dan Kida (2012); Liburd et al. (2015) dan Utami dan Nahartyo (2016) bahwa ambiguitas informasi menjadi hambatan dalam pengauditan. Kedua, penelitian ini memberikan bukti empiris bahwa informasi yang disajikan secara tidak cukup dan komplek akan menimbulkan ketidakakuratan dalam pengambilan keputusan audit. Hasil temuan tersebut mendukung penelitian Luippold dan Kida (2012) serta Utami dan Nahartyo (2016) bahwa informasi yang disajikan secara tidak cukup dan komplek akan menyebabkan ketidakakuratan dalam pengambilan keputusan jika dibandingkan dengan kedua level ambiguitas lainnya. Informasi yang komplek bukan berarti informasi tersebut cukup dan relevan untuk membuat keputusan, auditor akan cenderung membuat keputusan yang tidak akurat saat mendapatkan informasi yang komplek. Kecukupan informasi menunjukkan informasi tersebut relevan dengan informasi yang dibutuhkan.

\section{Implikasi penelitian Implikasi teoritis}

Hasil penelitian ini memberikan implikasi teori bahwa ambiguitas informasi meyebabkan ketidakakuratan. Penelitian ini memberikan kontribusi bagi pengembangan penelitian keperilakuan dalam menguji ambiguitas informasi. Hasil penelitian ini mendukung penelitian terdahulu yaitu Luippold dan Kida (2012), Liburd et al. (2015) dan Utami dan Nahartyo (2016), bahwa ambiguitas informasi berdampak negatif dan menjadi keterbatasan auditor dalam pengambilan keputusan.

\section{Implikasi praktis}

Bagi para akuntan publik (auditor), penelitian ini memberikan kontribusi terkait dengan teori ambiguitas informasi yang dapat berdampak negatif terhadap pengambilan keputusan audit. Perencanaan audit yang baik dan mencari informasi yang relevan dengan penugasan audit dapat menolong auditor terhindar dari terpaparnya ambiguitas informasi sehingga dapat mengambil keputusan dengan tepat.

\section{KETERBATASAN, DAN SARAN Keterbatasan}

Keterbatasan penelitian ini masih terfokus terhadap pengukuran kecukupan informasi, dalam instrumen penelitian belum mengukur kompleksitas informasi.

\section{Saran}

Penelitian lebih lanjut dari hasil penelitian ini masih sangat dimungkinkan. Pertama desain ekperimen perlu mengukur instrumen kompleksitas untuk menyempurnakan penelitian terdahulu. Kedua pengembangan lainnya adalah pemitigasian ambiguitas informasi dalam pengambilan keputusan audit dalam tatanan kelompok diskusi kecil dan besar.

\section{DAFTAR PUSTAKA}

Bamber, M. E., dan Snowball, D. 1988. An experimental study of the effects of audit structure in uncertain task en- 
vironments. The Accounting $R e$ view. Vol.63 No.3: 490-504.

Bedard, J. C., dan Biggs, S. 1991. Pattern recognition, hypotheses generation and auditor performance in an analytical task. The Accounting Review. Vol.66 No.3: 622-642.

Bhattacharjee, S., Mario, M., dan Moreno, K. K. 2013. Auditors' judgment errors when working on multiple tasks and in multiple client environments: A research summary and practice implications. Current Issues in Auditing. Vol.7 No.1: 1-8.

Bonner, S. E., dan Walker, P. L. 1994. The effects of instruction and experience on the acquisition of auditing Knowledge. The accounting review. Vol.69 No.1:157-178.

Cahyaningrum, C. D., dan Utami, I. 2015. Apakah tekanan ketaatan dan kompleksitas tugas berpengaruh terhadap kompleksita audit?. Universitas Kristen Satya Wacana.

Cianci, A. M., dan Bierstaker, J. L. 2009. The impact of positive and negative mood on the hypothesis generation and ethical judgments of auditors. $A u$ diting: A Journal of Practice \& Theory. Vol.28 No.2: 119-144.

Chung, J., dan Monre, G. 1998. The effects of gender and task complexity on audit judgement. Perth, Australia: Edith Cowan University. 1-28.

Einhorn, H. J., dan Hogarth, R. M. 1986. Judging probable cause. Psychological Bulletin. Vol.99 No.1: 3-19.

Griffith, E. E., Kadous, K., dan Young, D. 2016. How insights from the "New" JDM research can improve auditor judgment: Fundamental research questions and methodological advice auditing: A journal of practice dan theory. Vol.35 No.2: 1-22.

Haron, H., Ismail, I., Ibrahim, D. N., dan Aw, L.N. 2014. Factors influencing ethical judgment of auditors in malaysia. Malaysia Accounting Review. Vol.13 No.2.

Hogarth, R. M., dan Einhorn, H. J. 1992. Order effects in belief updating: The belief-adjustment model. Cognitive Psychology. Vol.24 No.1: 1-55.

Koonce, L. 1993. A cognitive characterization of audit analytical review. Auditing: A Journal of Practice and Theory. Vol.12: 57-76.

Liburd, B., Issa, H., dan Lombardi, D. 2015. Behavioral implications of big data's impact on audit judgment and decision making and future research directions. Accounting Horizons. Vol.29 No.2: 451-468.

Luippold, B. L., dan Kida, T. E. 2012. The impact of initial information ambiguity on the accuracy of analytical review judgments. Auditing: A Journal of Practice \& Theory. Vol.31 No.2: 113-129.

Prasita, A., Adi, P. H. 2007. Pengaruh kompleksitas audit dan anggaran waktu terhadap kualitas audit dengan moderasi pemahaman terhadap sistem informasi. Jurnal Ekonomi dan Bisnis Fakultas Ekonomi Universitas Kristen Satya Wacana. Edisi September 2007. $1-24$.

Utami, I., dan Nahartyo, E. 2016. Audit decisions: The impact of interactive reviews with group support system on information ambiguity. Asian Journal of Business and Accounting. Vol.9 No.1: 105-139. 